\title{
VIOLATION ON MAXIM OF COOPERATIVE PRINCIPLE IN THE SLOGAN
}

\author{
Fery Erga Permadi \\ English Department of UNIKOM \\ Feryerga.permadi@yahoo.com
}

\begin{abstract}
This study argued that violation on maxim of cooperative principle occurs in various type of communication such as in the slogan. This study uses theory from Grice about cooperative principle as main theory and theory about pragmatic context from Cipollone as supporting theory to analyze the data. Based on Grice, violation on maxim of cooperative principle divides into four; violation one maxim, two, three, and four. Cipollone divides pragmatics context into physical context, linguistic, social, and epistemic. In this study, descriptive analysis method is used in analyzing the data. This study is expected can help to understand the strategy of creating slogan that uses violation on maxim of cooperative principle. The result of this study shows that each violation causes other violation as occurs in the violation on maxim of relevance, which is triggered by violation on maxim of quantity.
\end{abstract}

Keywords: Cooperative Principle, Pragmatic Context, Slogan, Violation of Maxim Cooperative Principle

\section{Abstrak}

Penelitian ini berpendapat bahwa pelanggaran terhadap maksim prinsip kerjasama terjadi dalam berbagai macam jenis komunikasi salah satunya dalam slogan. Studi ini menggunakan teori Grice tentang prinsip kerjasama sebagai teori utama dan teori tentang konteks pragmatik Cipollone sebagai teori pendukung untuk menganalisi data. Berdasarkan Grice, pelanggaran terhadap maksim prinsip kerjasama dibagi menjadi empat; pelanggaran satu maksim, dua, tiga, dan empat. Cipollone membagi konteks pragmatik menjadi konteks fisik, linguistik, sosial, dan epistemic. Dalam studi ini, metode analisis deskriptif digunakan untuk menganalisis data. Penelitian ini dihareapkan dapat membantudalam memahami strategi dalam pembuatan slogan yang menggunakan pelanggaran terhadap maksim prinsip kerjasama. Hasil dari penelitian ini memperlihatkan bahwa masing masing pelanggaran dapat mengakibatkan pelanggaran lainnya seperti yang 
terjadi pada pelanggaran maksim relevan yang mana dipicu oleh pelanggaran terhadap maksim kuantitas..

Kata kunci: Prinsip Kerjasama, Konteks Pragmatik, Slogan, Pelanggaran Terhadap Maksim Prinsip Kerjasama

\section{Introduction}

Speaker uses maxim to deliver the messages to hearer. Maxim can be used to optimize the messages and the purposes of the communication. In slogan, maxim has purposes to optimize and persuade consumer to buy the product. Maxim of cooperative principle are divided into four kinds; maxim quantity, quality, relevance and manner. Maxim is purposed to make successful communication, but when someone uses more or less information, irrational, irrelevant and unclear, it means that the maxim is violated. When maxim is violated, it will bring an indication and the purpose of the violation, which the indication can be supported by the use of pragmatic context in the violated maxim. By looking at the urgency, this research focuses on an examination of the relationship between maxim violation and pragmatic context to the indication that occurs in the slogan.

The writer uses theory Grice (1975) about cooperative principle. Grice divided violation maxim of cooperative principle into four types, maxim violation of quantity, quality, relevance, and manner. Violation on maxim of cooperative principle can raise the indication.

This study is the study of the contextual meaning. It means that language meaning is related to the context. There are four types of pragmatics context according to Cippolone et al (1998), linguistic context, physical, social, and epistemic.

\section{Data Source}

For this study, the data were taken from the slogan in the book The Emperors of Coca Cola: The Man Who Built The Brand by Murray Eldred, published in 2008. The slogans of Coca Cola were chosen because the language in slogan is short but, in its use, it has many indications for either the speaker or the hearer. Therefore, the language of slogan is chosen to accommodate the complexity of pragmatic analysis through violation, as in this study.

\section{Method}

In collecting the data, several steps are applied. First the potential data are marked. Then, the marked data is recorded based on the indication of the violation. After that, the data that have been recorded is classified into four 
categories; one violation, two, three and four. There are several steps in analyzing data. First, the violation occurs in the data are identified. After being identified, the indication of the violation and the reason why maxim of cooperative principle is violated are explained. After the indication is explained, the use of pragmatic context in the violated maxim is explained based on the context. At the end, the conclusion of the analysis is given systematically. According to Sugiyono (2008), this study uses descriptive analysis method. Sugiyono (2008) stated " Metode deskriptif analisis merupakan metode penelitian dengan cara mengumpulkan data dan kemudian data data tersebut disusun, diolah, dan dianalisis untuk memberikan gambaran masalah yang ada" Based on the theory, it can be assumed that the method works initially on the collected data: which is from the slogan of Coca Cola in the book The Emperors of Coca Cola: The Man Who Built The Brand by Murray Eldred. From the selected data, the method addresses the issue on the specified topic of discussion. From this, the analysis reveals the description regarding the data.

\section{Theoretical Review}

This study uses cooperative principle from Grice (1975) as grand theory to analyze the violation from the book "Logic and Conversation". Grice (1975) said that a successful communication can be made when the information is as informative as it is required, clear, relevant and truth. When the speaker does not follow, it means that the rule of cooperative principle is broken. The rule of cooperative principle is called maxim. Maxim is violated when the speaker tells more or less information, unclear, irrelevant, and less precise. Based on Grice (1975) maxim violation are divided into four categories; violation on maxim quantity, quality, relevance and manner

\section{a. Violation on maxim quantity}

Based on Grice (1975:45) violation on maxim quantity occurs when you contribute more or less, than it is required. For example: "Baskin Robbins: $\mathbf{3 1}$ Flavors"

The example above is the slogan of Baskin Robbins. The slogan violates on maxim quantity because there is ellipsed element in the slogan. The ellipsed element is about the product. It is Baskin Robbins has 31 flavors.

\section{b. Violation on maxim quality}

Based on Grice (1975:46) violation on maxim quality occurs when you tell less precise information or invalid. For example: "Sealy: Like sleeping on a cloud" 
The example above is slogan from Sealy. The slogan violates on maxim quality because the slogan uses figurative language, which is considered as invalid information. The copywriter compares the product with the cloud that means the product is as soft as the cloud.

\section{c. Violation on maxim relevance}

According to Grice (1975:46) violation on maxim relevance occurs when the information is irrelevant. For example: "Dominos Pizza: You got $\mathbf{3 0}$ minutes"

The example above is slogan from Dominos Pizza. The slogan is considered to violate maxim of relevance because the slogan is about time and the product is Pizza that makes it irrelevant.

\section{d. Violation on maxim manner}

According to Grice $(1975: 46)$ maxim of manner is violated when the information is unclear or ambiguous. For example: "Chick-Fil-A: Eat More Chikin"

The example above is slogan from Chick-Fil-A. The slogan violates maxim of manner because the slogan gives unclear information by using obscurity. The word Chikin should be chicken but chikin is chosen that makes the information becomes unclear.

Other than uses Grice theory, this study uses Cipollone (1998) theory about pragmatic context. Pragmatic context are divided into four; physical, linguistic, social and epistemic context.

\section{a. Physical Context}

Based on Cipollone et al (1998) physical context is context that relates to place, action, and object in the utterance like describing the place situation, an action, or things. For example: "Sealy: Like sleeping on a cloud"

The example above is slogan from Sealy. The slogan uses physical context of pragmatic because the slogan describes the situation of place and action. The place is on the bed and the action is sleeping.

\section{b. Linguistic Context}

According to Cipollone et al (1998) linguistic context is context that relates to the accompanied utterance like linguistic phenomena. For example: "Guinness: My goodness, my Guinness!"

The slogan uses linguistic context. There is exclamation mark in the structure. The use of exclamation indicates strong feeling. It means that the copywriter wants to give good impression to the consumer. 


\section{c. Social Context}

Based on Cipollone et al (1998) social context is context that describes social relationship. For example: "Dominos Pizza: You got $\mathbf{3 0}$ minutes"

The example above is slogan from Dominos Pizza. The slogan uses social context. It can be seen from the word you in the slogan above. The word you shows the social relation.

\section{d. Epistemic Context}

According to Cipollone et al (1998) epistemic context is context that relates to the background knowledge of speaker. For example: "Sealy: Like sleeping on a cloud"

The example above is slogan from Sealy. The slogan uses epistemic context because the slogan is just copywriter's belief. The copywriter believes that the product is as soft as cloud.

\section{Findings And Discussions}

\section{Data 1}

\section{Good till the last drop}

The data violates on maxim quantity. It occurred because there is less information on the slogan regarding thing that is delicious and refreshing. It is occurred because there is ellipsed element of the slogan that makes the structure becomes incomplete. The ellipsed element of the slogan is about the product that is good till the last drop. The ellipsed element on the slogan is Coca Cola because the slogan is the slogan of Coca Cola so that the product that is good till the last drop refers to Coca Cola. By omitting the structure, the copywriter expects consumers become curious about what product is good till the last drop.

The violation on maxim quantity occurs because of the slogan provides ellipsed element and this is done to increase the curiosity of consumers, so that consumers will seek out what product is good till the last drop is. Thus, consumers are expected to look for the ellipsed element from the slogan, which will lead consumers find the ellipsed element then bring sense to try the product and prove whether the product is really good till the last drop or not.

Epistemic context is used in the slogan. The information in the slogan is Coca Cola is good till the last drop. Good till the last drop is the copywriter's belief about the product. The copywriter wants consumer believes that the product is really good till the last drop.

The data violates on maxim quantity by ellipsed the element about the offered product. This data uses epistemic context to raise the indication. 


\section{Data 2}

\section{The sign of good taste}

The data above violates maxim quantity because the slogan gives less information regarding thing that is considered as the sign of good taste. There is ellipsed element that supposed to be filled with the product that is Coca Cola. The copywriter deliberately ellipsed that to raise the curiosity of consumer about what is something that represent as the sign of good taste is. Thus, consumers will try the product by themselves to find out. Besides violates on maxim quantity, the data above also violates on maxim quality because the slogan is considered to present less precise information. The information in the slogan considered less precise because the slogan provides one of the figure of speech that is metaphor. Copywriter describes the product as sign of good taste. The use of metaphor in the slogan intended to make the product more alive, which is described as the sign of good taste. By making these products more alive, consumers are expected to be more interested in the product.

The slogan uses linguistic context and epistemic context because the slogan uses present tense. The use of the present tense can be considered as a truth. It can be said that copywriter wants the consumer to believe that what is advertised is a truth. The slogan Coca-Cola is the sign of good taste is just copywriter belief. The copywriter believes that the product is the best. This kind of pragmatic context is epistemic context.

The violations maxims are found in the data are violation on maxim quantity and maxim quality. Linguistic context and epistemic are used in this data.

\section{Data 3}

\section{Six million a day.}

The data violates some maxims. First, the slogan violates on maxim relevance because the structure of the slogan has no relation with the offered product. The slogan is something about six million a day. This information is considered has no relation with the offered product because of the second maxim violation. It is violating on maxim quantity. There is ellipsed element regarding thing that is sold. The element is ellipsed by copywriter so the information becomes less informative and makes the slogan has no relation with the product. The ellipsed element is about Coca Cola sales in a day or Coca Cola sold six million a day. The third maxim violation is violation on maxim quality. The structure provided in the slogan is considered as invalid because there is no supporting element that explain in the slogan is true, apart from that there is no statement 
from someone who is considered has credibility in that field that states the it is true, which makes this becomes invalid.

Although the slogan is considered as invalid, the copywriter uses six million a day in the slogan to attract consumer's attention. Six million is not small amount, so it will raise consumer's interest. They will think what makes this product can be sold over six million a day? Is it because the product is delicious? This curiosity will lead consumers to try the product.

Epistemic context of pragmatics is used in the slogan. The complete slogan is Coca Cola sold six million a day. Coca Cola sold six million a day is the copywriter's belief about the product. The copywriter wants consumer beliefs to what he beliefs that his product can be sold six million in a day.

To sum up, the maxim violation in the data are the violation on maxim relevance, quantity, and quality. The context of pragmatic that is used in this data is epistemic context.

\section{Conclusions}

In the finding and discussion, there are three data has been analyzed. The first data contains one violation on maxim of cooperative principle and uses epistemic context of pragmatic. The second data contains two and uses linguistic and epistemic. The third data contains three and uses epistemic. Based on the analysis, It is concluded that some violation causes other violation.

\section{References}

Cipollone, et al. 1998. "Language Files: materials for an introduction to Language and Linguistics". Columbus: Ohio State University Press.

Eldred, Murray. 2008. "The Emperors of Coca Cola: The Man Who Built The Brand": Lulu.com.

Grice, Herbert. 1975, "Logic and conversation." In Cole, P., and J.L. Morgan, eds. Speech Acts. New York: Academic Press.

Sugiyono. 2008. "Metode Penelitian Bisnis". Cetakan keduabelas. Bandung: CV. Alfabeta.

Yule, George. 1996. "Pragmatics". Oxford: Oxford University Press. 
